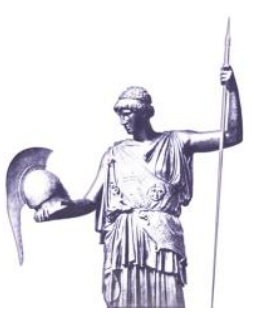

Research Article
Connections: The Quarterly Journal

ISSN 1812-1098, e-ISSN 1812-2973

János Besenyő, Connections QJ 16, no. 3 (2017): 23-45

https://doi.org/10.11610/Connections.16.3.02

\title{
Guerrilla Operations in Western Sahara: The Polisario versus Morocco and Mauritania
}

\section{János Besenyö}

Doctrine Concept Development Department, Hungarian Defense Forces

\begin{abstract}
This essay examines the guerrilla war fought between the Polisario Front, representing the Western Saharan natives, and the Kingdom of Morocco, as well as Mauritania. Even today, the aforementioned guerrilla war provides many lessons regarding desert counter-insurgency (COIN) operations. Besides reviewing the necessary activities for conducting a successful guerrilla war, this paper will delineate the most efficient methods for defending against one. This is the first COIN operation for the Moroccan government in which it has taken an unusual approach in standing up against the guerrillas. It has achieved long-standing results by the restructuring of its tactics and the units stationed in the Western Saharan region as well as by the construction of a system of fortifications.
\end{abstract}

Keywords: Western Sahara, Morocco, Mauritania, Polisario, Sahrawi, guerrilla.

\section{The Beginnings; Sahrawi Nationalism}

From the beginning of the 1970s, there were numerous views about the fate of the Western Saharan territories which had been occupied by Spain since the end of the $19^{\text {th }}$ century. ${ }^{1}$ The Spanish wanted to keep the territory as an "overseas

1 Janos Besenyő, "Western-Sahara under the Spanish Empire," Academic and Applied Research in Public Management Science (AARMS) 9, no. 2 (2010): 195-215. 
territory." 2 However, Morocco and Mauritania also had claims on the region, while the natives wanted to found their own, independent state. The Sahrawis, consisting of more than a hundred tribes, were represented by the Sahrawi National Union Party (PUNS) which had been created by and was entirely subservient to the Spanish, and the Frente Polisario, formed by the natives, who in the end joined forces to fight against the Moroccans and Mauritanians occupying the country after the withdrawal of the Spanish. The Polisario, founded in 1973, mounted an armed resistance, initially, against the Spanish. Their first attack was conducted on 20 May 1973 against a Spanish military checkpoint in El-Khanga. Soon the Polisario executed more attacks against other smaller military outposts as well as making repeated assaults against the phosphate mines of Bou Craa. They also damaged the phosphate transport systems linking the mines with the port. Then, the Spanish mobilized their military divisions in order to deal with them. In March 1974, Operation “Barrido" was launched, in which, besides the units of the Policia Territorial and the Tropas Nomadas, military helicopters were also used against the militiamen of the Polisario. At that time, the neighboring countries of Morocco, Mauritania and Algeria officially supported the self-determination of the region. Later though, Morocco and Mauritania demanded the territory for themselves. The Algerian president Bumedien protested about this, and began to support the Polisario from the summer of 1975, and subsequently recognized the Polisario as a liberation movement.

\section{Fight for the Spanish Sahara}

On 13 December 1974, the United Nations passed Resolution No. 3292 (XXIX) about the postponement of the referendum, the sending of a commission of inquiry to Western Sahara and the request for the opinion of the International Court of Justice in Hague. The UN commission visited the Western Sahara, Madrid and the capitals of the neighboring countries between 8 May and 9 June $1975 .^{3}$ The report of the commission made it clear that the natives supported the increasingly dominant Polisario and demanded an independent country. ${ }^{4}$ The Spanish, fearing that they would lose even their remaining influence in the region, started secret negotiations in Algiers with the leaders of the Polisario about the peaceful transfer of power. During the negotiations, the Polisario ceased its attacks against the Spanish. ${ }^{5}$ In the course of the negotiations, the Sahrawis offered the Spanish the use of the phosphate mines free of charge for another 20 years. The Spanish would also be allowed to keep most of their fish-

2 Geoffrey Jensen, War and Insurgency in the Western Sahara (Boulder, CO: Lynne Rienner Publishers, 2013), 9.

3 John Mercer, Spanish Sahara (London: George Allen and Unwin Publishers, 1976), 242-243.

4 Jensen, War and Insurgency in the Western Sahara, 13.

5 Pablo San Martín, Western Sahara: The Refugee Nation (Cardiff: University of Wales Press, 2010), 98. 
ing rights in the area. In response, the Spanish recognized the organization in a semi-official capacity. As they knew that Morocco were intent on the invasion of Western Sahara, the Frente Polisario attempted to try to win over Mauritania which was afraid of the Moroccan territorial demands. ${ }^{6}$ They offered Mokhtar Ould Daddah, the then Mauritanian president, the creation of a federal state under his leadership by uniting the two territories. ${ }^{7}$ However, the Mauritanian president was sure that the Moroccans could not be stopped and that the International Court of Justice would also support the Moroccan claims, so, he chose to cooperate with Morocco. The Spanish were unable to maintain their influence in Western Sahara, and in addition, Prime Minister Arias Navarro and his supporters were afraid that the Polisario, as a radical nationalist movement, might provide a base for the anti-Spanish Canary Islands Independence Movement (CIIM), that operated from Algiers at that time. ${ }^{8}$ Therefore, they eventually gave up the territory and on 14 November 1975, they concluded the Madrid Agreement with Morocco and Mauritania, who divided Western Sahara between themselves according to the treaty. ${ }^{9}$

On 15 November, El-Vali, the leader of the Polisario announced that they regarded the Madrid Agreement as null and void. Nevertheless, the Moroccan ruler Hassan II announced on 25 November that he viewed the Western Saharan issue as concluded and appointed Ahmed Bensouda as the governor of the region. The king reckoned that the Polisario leaders would not be able to rally the 60,000 Sahrawis and that they would only be able to utilize a few mercenaries for their operations, who, unlike the Moroccan military, would be unsuited to desert warfare. He thus concluded that the existence of the Polisario did not present a threat to the Moroccan state. He made this statement knowing about the reports that the 2,500 strong local military and police force, formerly employed by the Spanish, had almost entirely joined the Polisario. ${ }^{10}$ Many voiced their doubts about the military capabilities of the natives, for instance the U.S. ambassador wrote in his report that

Polisario, even though [the] guerillas' needs [are] probably few, would not seem capable of standing up for long against relative Moroccan military

6 Robert E. Handloff, Mauritania: A Country Study (Washington: Federal Research Division of the Library of Congress, 1990), 22-23, 27-28.

7 Toby Shelley, Endgame in the Western Sahara: What Future for Africa's Last Colony? (London and New York: Zed Books, 2004), 43.

8 John Damis, Conflict in Northwest Africa: The Western Sahara Dispute (Stanford, CA: Hoover Institution Press, 1983), 65.

9 Hammad Zouitni, The Moroccan Sahara Issue from the Independence of Morocco to the Present Day (Centre Marocain Interdisciplinaire des Études Stratégiques et Internationales, 2013), 239.

10 Janos Besenyő, "The Occupation of Western Sahara by Morocco and Mauritania," Tradecraft Review 6, no. 1 (Special Issue, 2010): 76-94, http://www.scribd.com/doc/ 127198909/The-Occupation-of-Western-Sahara-by-Morocco-and-Mauritania. 
might and in a highly inhospitable environment where spotting from [the] air [is] relatively easy.

The position of the International Institute for Strategic Studies was also similar:

[G]uerilla operations are difficult in the open desert of Spanish Sahara, where it is relatively easy for a defender to control movement. ${ }^{11}$

The critics of the capabilities of the natives did not take into account that the Sahrawis had lived in the area for centuries and were acclimatized to its peculiarities. Knowing all the caravan routes, passable paths and water sources, they could use all the opportunities provided by the desert against the Moroccan troops. According to some analysts, the Moroccan military was much better prepared than the Sahrawis, since they had not only conducted a liberation war against the French for years, but Moroccan soldiers had also served with UN Forces in the Congo (1960-61). In addition, they had participated in a short border conflict against Algeria in 1963 as well as fighting in Syria during the 1973 Arab-Israeli war. The Moroccan military equipment was considered to be some of the most advanced in the region at that time, thus it is understandable that everyone expected them to be victorious. However, the Moroccans had not taken into consideration the experience of the former Spanish colonials, who had conducted a quite effective counter-insurgency operation, with the participation of paratroopers and other special forces, against units of the Moroccan Liberation Army during the Ifni War. ${ }^{12}$

\section{The Occupation of Western Sahara}

In the middle of November 1975, the Moroccan military began its advance into Western Sahara. At the same time, the Spanish announced that within a few months they would be dismantling the civilian administration and starting to pull out their forces, whose places would be taken over by Moroccan and Mauritanian soldiers. ${ }^{13}$

The goal of the troops advancing along the coast was the occupation of ElAaiun and the phosphate mines of Bou Craa. According to the first official military reports, the Royal Forces moved 100 kilometers deep into Western Saharan territory, and on 28 November they captured the second largest settlement,

11 Stephen Zunes and Jacob Mundy, Western Sahara: War, Nationalism and Conflict Irresolution (NY: Syracuse University Press, 2010), 6-7.

12 The Moroccan military leadership paid dearly for its forgetfulness, both in manpower and in material losses, since there were many Sahrawis in the units of the Frente Polisario, who had fought side by side with the Spanish as soldiers of the Spanish Legion or the Nomadic Troops (Tropas Nomadas) in order to expel the Moroccan troops infiltrating Spanish Sahara.

13 David J. Dean, The Air Force Role in Low-intensity Conflict (Maxwell Air Force Base, AL: Air University Press, 1986), 33. 
Smara. ${ }^{14}$ In less than a month, a 25,000 strong force, about the third of the Moroccan army, was positioned in the Western Saharan region. Of these, 15,000 were stationed in the garrisons of Saguia El-Hamra, 5,000 in El-Aaiun, while another 5,000 were based near the southern borders of the late Spanish Sahara. The advances of the Moroccan troops were followed by a mass migration of the populace. An associate of the U.S. embassy in Rabat, who was present in the area, wrote about the events as follows: "the civilian population of the cities has almost entirely disappeared," while the ambassador himself described the Moroccan-occupied cities of El-Aaiun and Smara as "virtual armed camps." ${ }^{15}$ On 11 December, the Moroccans captured El-Aaiun, while the Mauritanians, also on the offensive, occupied La Guerra and Tichla. The Spanish had retreated from the region by the end of December, with the last Spanish soldier leaving the territory of the former Spanish Sahara on 12 January 1976. Afterwards, only 150 Spanish officials were left behind to execute and observe the seamless transition between Spanish and Moroccan administration of the territory. ${ }^{16}$ Soldiers of local origin, relieved from Spanish military duty, joined the Polisario-formerly regarded as an enemy by most of them-and organized the Saharan People's Liberation Army (Ejército de Liberación Popular Saharaui; ELPS) in order to fight the Moroccans. ${ }^{17}$ The Sahrawis utilized Algerian and Vietnamese models for the establishment of their armed forces. The leaders of the resistance, morally more committed than the Moroccan and Mauritanian soldiers, showed an unexpected tactical ability during the guerrilla operations that followed. ${ }^{18}$ The Sahrawis also received armaments from the withdrawing Spanish troops and, in certain cases, even some fortifications were handed over by the Spanish. ${ }^{19}$ Initially, the poorly armed Sahrawis conducted mainly defensive operations, and helped to evacuate the civilian population in flight because of the brutality of the Moroccan troops.

However, the Sahrawis were soon on the offensive. One of their smaller groups had attacked the Mauritanian city of Zuerat already on 29 December. The city, which operates as a mining center, is located in the middle of the desert, about 400 kilometers from the capital. During the attack, the Sahrawis managed to inflict minor damage to the mining equipment, but they were unable to capture the city. At that time, the Mauritanian army consisted of less than 3,000 trained troops, 2,000 military policemen and a few aging fighter planes, thus it was an easier target for the Sahrawis, who used guerrilla tactics to continuously

14 Richard Lawless and Laila Monahan, War and Refugees: The Western Sahara Conflict (London and New York: Pinter Publishers, 1987), 99.

15 Zunes and Mundy, Western Sahara: War, Nationalism and Conflict Irresolution, 113.

16 Tony Hodges, Western Sahara: Roots of a Desert War (Westport, CT: Lawrence Hill Books, 1983), 229-230.

17 Damis, Conflict in Northwest Africa, 70-71; Virginia M. Thompson and Richard Adloff, The Western Saharans: Background to Conflict (London: Taylor \& Francis, 1980), 252.

18 Jensen, War and Insurgency in the Western Sahara, 31-34.

19 Zunes and Mundy, Western Sahara: War, Nationalism and Conflict Irresolution, 9. 
harass the Mauritanians. ${ }^{20}$ Ain Ben Tili, the famous former fortress of the French Foreign Legion was defended by Mauritanian soldiers when the fortress was surrounded by Sahrawi units. The Mauritanian President Ould Daddah asked for the assistance of the Moroccan air force to relieve the defenders who were in a tight situation. However, even the Moroccan air force was incapable of relieving the fort. Moreover, one of the Northrop F-5 fighters was shot down by the guerrillas. The fort was finally captured by Polisario troops on 21 January. In the following days, the guerrillas attacked the cities of Bir Moghrein and Inal, but, while they succeeded in causing major damage, they could not capture the cities due to the coordinated counterattack of the Mauritanian army. The Mauritanians managed to reorganize their troops, with French assistance, and went on the counter-offensive on the Western Saharan border in the third week of December. After a short but bloody battle, they captured the city of La Guerra and began to drive out the Polisario soldiers and sympathetic civilians from the area. On 11 January, the Mauritanians managed to occupy the small city of Argoub (near Villa Cisneros) only after two weeks of fighting. The 200 civilians and soldiers defending the city fought until the last bullet and the Mauritanians were only able to capture a few seriously wounded soldiers, as the majority of the defenders had died during the battle. Afterwards, the Sahrawis were left with only one choice: flight. ${ }^{21}$ The refugees first aimed for the northern territories of Mauritania bordering Western Sahara. Then they were evacuated to Algeria with the help of the Algerian army. ${ }^{22}$ Besides transportation of the refugees, the Algerians also assisted the Sahrawi troops with food, water and medicine. ${ }^{23}$ The first signs of a split in the Morocco-Mauritania alliance were already visible at this time. The Moroccans, fearing that the Mauritanian troops would be unable to capture Villa Cisneros by the designated deadline, marched into the city under the leadership of Colonel Dlimi. In spite of the fact that the Madrid Accords placed the city under Mauritanian supervision, Morocco deployed a garrison there. Thus, while Mauritania created an administrative center in the city, the actual military power was represented by Morocco. ${ }^{24}$

On 27 January 1976, the units of the Moroccan army attacked an Algerian convoy conducting "humanitarian activities" near Amgala, ${ }^{25}$ and after several

20 The Sahrawi possessed very accurate information about the Mauritanian situation, as several Sahrawi leaders-like Ibrahim Hakim or Ahmed Baba Miske, the latter having served earlier as a Mauritanian diplomat-originated from Mauritania, and they could also count on the assistance of the Sahrawis living in the country.

21 Hodges, Western Sahara: Roots of a Desert War, 231.

22 Janos Besenyő, "Saharawi Refugees in Algeria," Academic and Applied Research in Public Management Science (AARMS) 9, no. 1 (2010): 67-78.

23 Norrie MacQueen, United Nations Peacekeeping in Africa Since 1960 (London: Longman, 2002), 237.

24 Hodges, Western Sahara: Roots of a Desert War, 230-231.

25 The Algerians conducted mainly the transportation of the Sahrawi refugees, but also provided logistical support for the militants of the Polisario. 
days of fighting, the Algerian troops had to retreat having suffered a serious defeat. ${ }^{26}$ The enraged Algerian military leadership demanded immediate retaliation, and the onset of a war was just about avoided. From then on, while the Algerian leadership increased its material support for the Sahrawi militants, it kept its troops away from any further clashes. ${ }^{27}$ Retribution arrived soon, as in the second battle of Amgala between 13 and 15 February, units of the Polisario defeated the Moroccan troops.

At this time, being equipped with French weapons and coordinated by French military trainers and in spite of the low military capabilities of the Mauritanian troops, the Moroccan-Mauritanian alliance was in a better position than the guerillas. ${ }^{28}$ The guerrillas could muster only several thousands of volunteers equipped with small arms, mortars and a few anti-tank and anti-aircraft missiles that they received from the Libyan and Algerian militaries. ${ }^{29}$ During the clashes, the Moroccans did not just deploy infantry units, but on multiple occasions they also bombarded the settlements and the refugee camps of the Sahrawis. ${ }^{30}$ This led to an increased migration of the civilian population from the occupied territories. At first, only 9,000 refugees lived in the camps built in the desert but, by the end of 1975, there were reports of around 70,000 people, ${ }^{31}$ and by the end of February 1976, about 100,000 women, children and the elderly were housed in the refugee camps in Algeria. ${ }^{32}$ Most of the men had gone to war. The Sahrawi Arab Democratic Republic was proclaimed on 27 February 1976 and war was declared against Morocco and Mauritania. ${ }^{33}$ Still, the Moroccan army continued its offensive and occupied more and more territory.

On 14 April 1976, the allies officially signed a treaty about the division of the region. In the treaty, Morocco received the two largest cities (El-Aaiun and Smara) and the phosphate mines, thus increasing its existing territories by ap-

26 Shelley, Endgame in the Western Sahara, 26-27.

27 Dean, The Air Force Role in Low-intensity Conflict, 35-36.

28 Thompson and Adloff, The Western Saharans, 270.

29 Anthony H. Cordesman, A Tragedy of Arms: Military and Security Developments in the Maghreb (Westport: Praeger Publishers, 2001), 59.

30 The Moroccans deployed not only conventional bombs, but also napalm and white phosphorus against the Sahrawis. See: Jensen, War and Insurgency in the Western Sahara, 16; and Erik Jensen: Western Sahara: Anatomy of a Stalemate (CO: Lynne Rienner Publishers, 2004), 29.

31 San Martín, Western Sahara: The Refugee Nation, 109.

32 According to some researchers, the separation between different tribes has practically vanished in the refugee camps, thus it could be observed that the formation of a Sahrawi nation was helped by them being refugees. For that matter, according to a lot of researchers and the Moroccan official stance, there is no Sahrawi nation, the concept was created artificially in the $20^{\text {th }}$ century. This is partially true as the Polisario has strived actively and very successfully to dissolve the bonds of the former tribal system, as it would weaken the unity of the Sahrawi people in their opinion. See: Jensen, War and Insurgency in the Western Sahara, 16, 24-26, 29-30.

33 Damis, Conflict in Northwest Africa, 40-44. 
proximately 35 percent. ${ }^{34}$ Meanwhile Mauritania, while it received Villa Cisneros and a long shoreline with good fishing capabilities, had nothing else but desert sand on the territory it received. ${ }^{35}$

\section{Guerrilla War against the Occupying States}

The Polisario continued the fight after the division of the region. A series of attacks known as the "20 May offensive" peaked on 11 May when a coordinated offensive was launched against El-Aaiun, Smara, Bou Craa, Bir Moghrein and Chinguetti, as well as on the conveyor belt system transporting phosphate. ${ }^{36}$ The guerrillas, roused by the successes of these smaller ambushes, attacked even Nouakchott, the Mauritanian capital, in the early hours of 8 June $1976 .{ }^{37}$ The military unit, consisting of about 600 troops, managed to cover 1,000 kilometers undetected in enemy territory, which was evidence of an excellent understanding of the local geography and the support of the local populace. The attack lasted for almost an hour, the targets were showered with mortar and machinegun fire. Some of the Mauritanian troops fled, but the Sahrawis could not exploit their victory as their leader, El-Wali Mustafa Sayed, was killed during the battle. ${ }^{38}$ At the same time, the Polisario launched attacks in the northern territories against Tan-Tan, Jdiria and Guelta Zemmour. The Sahrawis had changed their tactics by then. Realizing that they could not effectively defend the settlements they still controlled against the motorized and modernized Moroccan units, they shifted to well-known and more successful guerrilla tactics. ${ }^{39}$ In almost every attack, they could rely on the support of a large part of the local population, since there were tribes related to the Sahrawis in both the South Moroccan and the Mauritanian territories. Thus, numbering several hundred troops, the Polisario units could move easily in both the occupied territories and those of the hostile countries. Hence, while the Moroccans held the cities and the fortifications handed over by the Spanish, their supply lines were constantly under attack $^{40}$ by the militants who were aided by their extensive knowledge of the diverse terrain of the region. ${ }^{41}$

34 Cordesman, A Tragedy of Arms, 60.

35 Yahia H. Zoubir, "The Western Sahara Conflict: Regional and International Dimensions," The Journal of Modern African Studies 28, no. 2 (June 1990), 226.

36 Dean, The Air Force Role in Low-intensity Conflict, 42.

37 Damis, Conflict in Northwest Africa, 84.

38 Zunes and Mundy, Western Sahara: War, Nationalism and Conflict Irresolution, 11; Handloff, Mauritania: A Country Study, 30.

39 David L. Price, The Western Sahara (Beverly Hills, CA: Sage Publications, 1979), 33.

40 Jim Paul, et al., "With the Polisario Front of Sahara," MERIP Reports 53 (December 1976): 16

41 Generally, the desert is less suited for guerrilla warfare, but the majority of Western Saharan territories are covered by low mountains and decorated with seasonal river valleys and gullies where a large number of caves provides plenty of opportunities for hiding. Moreover, unlike the occupying forces-who have to get all their supplies from 


\section{The Role of Mauritania in the Conflict}

Mauritania was, militarily, the weaker of the two countries and was also troubled by internal economic and ethnic issues. Therefore, the Polisario focused its limited resources on the fight against Mauritanian troops. The Sahrawis, in the spirit of the Saharan Arab traditions and lacking training and adequate heavy weaponry, organized guerrilla attacks (ghazzi). Their units (kata'ib), equipped with small arms and Land Rovers, appeared, after travelling hundreds of kilometers, and then disappeared after quickly executed attacks. ${ }^{42}$ Since the Mauritanian desert is almost twice the size of France, the military and police forces at the disposal of local authorities were insufficient to control the territory.

As the Sahrawis realized that they are not capable of defeating the Mauritanians solely by military means, they also applied political and economic pressure on the country. They systematically harassed economic targets in order to turn the civilian populace against the government. The continuous attacks launched by the militants damaged the railways connecting the Mauritanian iron mines with the ports causing severe problems for the country, whose main source of income was the sale of iron ore. ${ }^{43}$

While the Mauritanian political leadership was astonished by the attacks, it thought that quick changes in the military leadership could resolve the situation. Lieutenant-Colonel Ahmed Ould Bouceif, who had formerly led the second military district in the country, was appointed as the new chief of staff. At the same time, the Mauritanian leadership voiced its first criticisms of the actions of the Moroccan military, as they expected the Moroccans to launch a counter-offensive against the Polisario units. However, it was the militants of the Polisario who launched an attack from the Moroccan-occupied zone against the Mauritanian settlements of Nema and Tisitt.

Due to the intensifying attacks, the Mauritanian army increased its numbers to 17,000 and bought more modern weapons. ${ }^{44}$ In the city of Atar, the training of freshly recruited soldiers was accelerated in the military training center, which was created with French support, but even this could not achieve significant re-

outside - the Sahrawis have been living in the area for centuries and know every water spring. The armies occupying the region could not effectively recon the guerrillas, even by aerial reconnaissance: the Sahrawis had learned during their fight against the French and Spanish that they could defend against aircraft by moving at night and hiding at day. The Moroccans thought that by equipping their aircraft with infrared detection systems, they could spot and destroy Polisario forces effectively. While they procured a Westinghouse radar system with U.S. support, it did not live up to the expectations, partly due to the huge territory, partly due to the low number of radars and the insufficient training of the Moroccan operating personnel. See: Jensen, War and Insurgency in the Western Sahara, 18-19.

42 Dean, The Air Force Role in Low-intensity Conflict, 42; Thompson and Adloff, The Western Saharans, 253.

43 Handloff, Mauritania: A Country Study, 5.

44 Shelley, Endgame in the Western Sahara, 43-44. 
sults. ${ }^{45}$ On 9 May 1977, the insurgents again raided the Mauritanian city of Zuerat and so severely damaged the power plant, the fuel tanks and the mining equipment, that production had to be halted temporarily. At this time, Mauritania could only remedy its problems in the Western Sahara with the military aid provided by agreement with Morocco, and with the financial support from Saudi Arabia, Kuwait, Côte d'Ivoire ${ }^{46}$ and the United Arab Emirates. ${ }^{47}$ In spite of the presence of the freshly arrived Moroccan troops, units of the Polisario attacked Nouakchott again in July, retreating with minimal casualties after a successful attack. ${ }^{48}$

The French, as allies of the Mauritanians, sent in a 200-strong military unit to secure the Mauritanian capital, and from the end of November, Jaguar fighter aircraft were directed from the Dakar airbase to reinforce the defense of larger Mauritanian settlements in an offensive known as "Operation Lamantine." The situation in Mauritania worried the French greatly as the country was in their military and economic sphere of interest. In spite of Mauritanian statements emphasizing their independence from France, the country was still linked to its former colonizer. During "Operation Lamantine," part of the supersonic fighter aircraft at the Oukkam airbase in Senegal were placed on alert because they could reach the area of Nouakchott in less than 50 minutes. The 1,300 French soldiers deployed at the base were reinforced by another $300^{49}$ and, on the night of 1 November, a unit of rapid deployment forces under the leadership of General Michael Forget arrived at the base in Senegal. Within days, the General redeployed with 60 specially trained soldiers to the city of Atar in Mauritanian territory. The command of the Ouakkam base was taken over by Colonel Huret, who was also responsible for the logistical support of "Operation Lamantine." Soon after his arrival, Forget began to establish communication lines between Ouakkam and the Mauritanian bases. In the meantime, the Breguet-Atlantic aircraft provided by the French Navy conducted surveillance patrols above Mauritania. ${ }^{50}$ The aim of the surveys was to observe the movement of Polisario troops and

45 Hodges, Western Sahara: Roots of a Desert War, 246.

46 Jensen, War and Insurgency in the Western Sahara, 39.

47 Damis, Conflict in Northwest Africa, 85.

48 By the end of April 1977, Polisario militants had destroyed 18 fighter planes and helicopters, two transport planes and 600 of various military vehicles and trucks. Of the allies, the Moroccan casualties were 4,200 dead, 2,800 wounded and 96 captured, while the Mauritanian casualties were 1,600 dead, 900 wounded and 16 captured. Certain sources explained the low number of captives with the initial unwillingness of the Sahrawi to take prisoners. Despite inflicting heavy casualties, the Polisario could not achieve substantial successes against the occupying forces. See: Jensen, War and Insurgency in the Western Sahara, 36.

49 Zunes and Mundy, Western Sahara: War, Nationalism and Conflict Irresolution, 12.

50 While these aircraft were initially designed to detect submarines, they proved to be an important part of the operation with their trained crew. The French used also Mirage-4 long-range surveillance aircraft to map the less known areas and take photographs. 
then inform the French fighter planes and the Mauritanian military and police units who were ready to counterattack. The French advisors also created maps for the units of the Mauritanian army, as they were not familiar with the territories occupied by them. The French secret service also recruited experienced mercenaries to support the Mauritanian soldiers. At the request of the Mauritanian government, the Moroccans also sent troops to support the operations. ${ }^{51}$

It seemed that the soldiers of Polisario could not withstand such a force, and so Mauritania restarted rail traffic on the Nouadhibou-Zuerat railway, which had been out of commission for a month. However, the Sahrawis attacked the first shipment, capturing the French train engineer and the Mauritanian soldiers escorting the shipment. On 25 November, the irate French deployed another four Jaguar military aircraft from the Toul airbase to Mauritania, to involve them in the retaliatory strikes against the Polisario. ${ }^{52}$ The Jaguars were deployed first on 2 December against guerrillas attacking the railway near the settlement of Boulanour and then on 12 December near Zouerat. While "Operation Lamantine" caused a lot of damage to the guerrillas, it did not stop them. On the contrary, the Sahrawis learned from these experiences and, after splitting into smaller groups, they led further raids against Mauritanian targets. ${ }^{53}$ Between 1977 and 1978, their attacks halted the rail traffic between Nouadhibou and Zuerat almost completely, paralyzing the iron mining operations that constituted a major part of Mauritanian revenue.

Despite a sharp decline in governmental income, Mauritanian military expenditure was increased by almost 50 percent in 1976 and by another 26 percent in 1977, amounting to about 30 percent of the total government expenditure. Mauritania could only manage to maintain order by calling in more Moroccan troops, but the guerrillas were not to be stopped by this, and the trust of the military leadership was shaken by the government's reliance on a MauritanianMoroccan alliance. ${ }^{54}$ Several Mauritanian officers of Arab origin felt that their national pride was dishonored by leadership of the war being taken over by the Moroccans, forcing Mauritania into a secondary role..$^{55}$ On 10 July 1978, the dis-

51 The Moroccans had sent additional 600 soldiers to the territories occupied by Mauritania, where soon 1,200 Moroccan troops were deployed, and even more arrived from Morocco. In January 1978, already 2,400 soldiers were stationed in the area of Zouerat-Nouadhibou, 600 at the iron mines of Akjouj, and other 2,800 near Tiris el-Gharbia. The Moroccan air force has also deployed three F-5 fighter aircraft to the Nouadhibou airport, so that they could participate in the joint operation.

52 Price, The Western Sahara, 62.

53 Tony Hodges, "The Western Sahara File," Third World Quarterly 6, no. 1 (January 1984): 74-116, 101-102.

54 Lawless and Monahan, War and Refugees, 101.

55 In Mauritania and Tiris el-Gharbia, 8,000 Moroccan soldiers were serving in February 1978 , but their numbers soon rose above 9,000, raising French concerns, too. The Polisario accused the Mauritanian leadership of attempting to hand over the country to the Moroccans. The resulting panic is well shown by the fact that the Mauritanian 
contented officers overthrew Mokhtar Ould Daddah and initiated talks with the Sahrawis about the possibility of a peace treaty. ${ }^{56}$ In response, the Polisario announced a unilateral truce with Mauritania with effect from 12 July. As more than 8,000 Moroccan troops were stationed in Mauritania, ${ }^{57}$ the government had very tight margins and could not, simultaneously, fulfill the demands of Morocco, Algeria and the Polisario. Once again, France was asked to mediate. However, it soon became apparent that Mauritania could not make a unilateral decision about a peace treaty with the Polisario. So, recognition of the Sahrawi Arab Democratic Republic (SADR) and the immediate and unconditional withdrawal from the Mauritanian-occupied territories was out of the question.

As the ceasefire did not extend to the Moroccans, on 4 January Sahrawi troops crossed the Draa river, which served as a historical and physical border, and attacked the Moroccan city of Assa. After this successful border raid, the Sahrawi launched the "Bumedien Offensive," named after the former Algerian president. ${ }^{58}$ The first attack was launched on 16 January 1979 near the settlement of Lemseid, less than ten kilometers from Laayoune. During the two days of this battle, two major Moroccan battle columns were destroyed. This was the first case of a motorized Moroccan unit, accompanied by armored vehicles, suffering a defeat against Western Saharan soldiers. The Polisario reported 600 dead, 250 wounded and 51 captured Moroccan soldiers and officers. They managed to capture four armored fighting vehicles and 60 off-road vehicles and to destroy seven tanks, 96 jeeps, a F-5 fighter aircraft and four helicopters. The Algerian president, Bendjedid Chadli, roused by the successes of the Sahrawis, asked Ould Salek to initiate peace talks as soon as possible. The Polisario entered Moroccan territory again on 28 January with a 1,200-strong unit equipped with modern weapons and 200 jeeps. The attackers managed, for a few hours, to capture the city of Tan-Tan in the center of South Morocco, which was a logistical center and a base of the Moroccan air force. After this successful raid, the attackers retreated into the desert with some captured Moroccan soldiers. The fact that they managed to cover 500 kilometers undetected in a territory controlled by the Moroccan military caught the attention of the global media and so, while the Moroccans denied the raid having taken place, the world became aware of the attack. ${ }^{59}$

In the meantime, there was another coup in Mauritania and the new leadership was willing to sign a peace treaty with the Sahrawis. On 5 August 1979 in Algiers, Mauritania and the Polisario signed the peace treaty, according to which Mauritania recognized the Polisario and revoked all of its territorial claims in

political leadership has asked again for the assistance of the French air force against the guerrillas attacking the capital in May 1978.

56 Handloff, Mauritania: A Country Study, 121-122.

57 Leo Kamil, Fueling the Fire: U.S. Policy and the Western Sahara (Trenton, NJ: The Red Sea Press, 1987), 36.

58 Dean, The Air Force Role in Low-intensity Conflict, 44.

59 Hodges, Western Sahara: Roots of a Desert War, 285. 
Western Sahara. ${ }^{60}$ In a secret clause of this Algiers Peace Treaty, the Mauritanians would have to hand over the Mauritanian-occupied territories to the militants of the Polisario within seven months of the signing of the treaty. ${ }^{61}$ However, this never happened. On 8 August, Hassan II ordered all his Moroccan troops stationed in Mauritania to return to Morocco, except for the 1000-strong unit in Bir Moghrein and the 2400-strong unit in Tiris el-Gharbia. The next day M'hammed Boucetta, the Moroccan minister for foreign affairs, announced that his country would reject the Algiers Treaty because Tiris el-Gharbia belonged, both historically and legally, to Morocco, and that this was supported by a decision of the International Court of Justice in The Hague. Afterwards, five Hercules C-130 transport planes arrived in Dakhla with several hundred Moroccan soldiers on board. They, along with the soldiers already stationed there, proceeded to occupy the city. In a few days, they took control of the whole of the former Mauritanian-occupied territory which they swiftly annexed to Morocco under the name Oued Eddahab. ${ }^{62}$ Thus, 95 percent of the Western Sahara came under Moroccan control. ${ }^{63}$ Later, Morocco took part in an unsuccessful coup against the Mauritanian President Haidalla in order to involve Mauritania again in the fight against the Polisario, but the country has consistently stayed away from the conflict since then. ${ }^{64}$

\section{The War between Morocco and the Polisario}

The guerrillas now turned their attention towards the Moroccan troops, whose situation had deteriorated following the withdrawal of the Mauritanians. Despite this, the Sahrawis could only achieve limited success against the better equipped regular forces. ${ }^{65}$ They returned again to guerrilla tactics against the Moroccans, who had founded several garrisons in the occupied territories. These, they had great difficulty in defending, as they failed to adapt well to the desert conditions. The militants of the Polisario created small outposts in the valley of the Saguia el-Hamra and the Zemmour mountains, most of them hidden underground, from where they launched their night raids and to where they could retreat from their pursuers. In order to evade aerial surveillance, they moved at night or, if they had to travel at day, they used jeeps from which all glass had been removed so that the reflection could not give away their posi-

60 Dean, The Air Force Role in Low-intensity Conflict, 42; Handloff, Mauritania: A Country Study, 33-34.

61 Hodges, Western Sahara: Roots of a Desert War, 275.

62 Janos Besenyő, A nyugat-szaharai válság egy magyar békefenntartó szemével, [The Western Saharan crisis through the eyes of a peacekeeper] (Pécs: Publikon Publishers, 2012), 139; Jensen, War and Insurgency in the Western Sahara, 17.

63 Zouitni, The Moroccan Sahara Issue from the Independence of Morocco to the Present Day, 242.

64 Handloff, Mauritania: A Country Study, 35.

65 Cordesman, A Tragedy of Arms, 61. 
tion. ${ }^{66}$ The favored targets for their attacks were Laayoun, Tarfaya and the bridge linking the cities of Tan-Tan and Tarfaya over the river Oued Chebeika. ${ }^{67}$ They also targeted the phosphate mines at Bou Craa, where, in the same manner as the attacks in Mauritania, they made the exploitation and transportation of phosphate almost impossible. ${ }^{68}$ Their main target was the 100 kilometer-long conveyor belt that transported the phosphate from the mines to the port area of El-Aaiun. The attackers were able to damage the conveyor belt at a number of points, and while the Moroccans worked to repair the damage and defend the area with patrols, they could not press their attack against the rebels. Due to the Polisario raids, phosphate mining was halted almost completely in the Western Saharan region, and its exploitation could continue only after the establishment of the Berm, a defensive wall system conceived by General Dlimi. But, as Morocco also has its own phosphate mines, mining and export was not completely halted by the Polisario raids. ${ }^{69}$

What was most unsettling for the Moroccan leadership was that the Polisario units had already begun to attack economic and military targets in the southern territories of Morocco. One target of the guerrillas was the settlement of Sidi Amara in the valley of the river Draa, where, on 27 August 1979, they managed to ambush a unit of the Moroccan army and destroy it almost completely. And on 30 September, the border post of Guelb Ben Rzouk near the Algerian border was captured..$^{70}$ The Polisario warned the Moroccan ruler that if his troops did not leave the territories of Western Sahara, the raids would continue and the Sahrawi militants would even attack the cities of Rabat, Agadir or Tangier. However, these were actually hollow threats, as the Sahrawis were only active in the Quarkziz and Bani mountains, the valley of the river Draa and certain areas of the Atlas mountains, and they never reached the aforementioned cities. ${ }^{71}$

Unlike the other opposing forces, the Moroccans received substantial financial and military support from the United States, ${ }^{72}$ France and South Africa. The arsenal of armaments used by them was quite extensive, they possessed F- 5 and

66 Hodges, Western Sahara: Roots of a Desert War, 283, 337.

67 Lawless and Monahan, War and Refugees, 103.

68 Shelley, Endgame in the Western Sahara, 191.

69 Thompson and Adloff, The Western Saharans, 291.

70 Hodges, Western Sahara: Roots of a Desert War, 285.

71 Neil Clough, Western Saharan Conflict: Prolonged Conflict and Prospects for the Future (Maxwell Air Force Base, AL: Air Command and Staff College, Air University. 2008), 8.

72 Morocco is the oldest ally of the United States in the Arab world (since 1786!), and it plays an important role in U.S. strategic planning. The commitment of the U.S. is shown by the fact that during the Western Saharan conflict, the U.S. not only provided financial support and armaments, but also intelligence and military advisors for the Moroccans. See: Jensen, War and Insurgency in the Western Sahara, 1-2, 45-46; Zoubir, "The Western Sahara Conflict," 233-234. For additional information on the Moroccan-U.S. relations see: Mohamed Sellak, United States - Moroccan Relations (Maxwell Air Force Base, Alabama: Air Command and Staff College, Air University, 1991). 
C-130 military aircraft, "Gazelle" helicopters, Ratel, Eland and AML-90MM armored personnel carriers, South African MK-6 armored reconnaissance vehicles, diverse anti-aircraft batteries, radar equipment and a large number of small arms. These countries did not only send arms, but also trainers and advisors for the Moroccans. Moreover, France provided considerable surveillance and training support for the Moroccan military. ${ }^{73}$ Of course, other countries also supplied the Moroccans with weapons, which was largely financed by Saudi Arabia. ${ }^{74}$ These included Egypt, Iran (before the 1979 revolution), Belgium, Italy, Jordan, Libya, ${ }^{75}$ Iraq, Brazil and Spain. ${ }^{76}$ According to certain researchers, Egypt, Iran and Jordan did not support Morocco with their own weapons, but with those that they had received from the U.S. ${ }^{77}$ At the same time, the Moroccans also bought arms from the Soviet Union and Romania. ${ }^{78}$ They continuously increased their defense budget, and proportionately the numbers of those serving in the army and the military police.

The Sahrawis possessed mainly Soviet-produced arms that they received from Algeria, Cuba, Libya and sometimes from North Korea. ${ }^{79,80}$ They included SA-6 and SA-7 anti-aircraft missiles, the ZSU-23 self-propelled anti-aircraft gun, various anti-tank weapons, guns, the BMP-1 armored vehicles and a few T-54 and T-55 tanks. This arsenal was expanded by the French and U.S. weapons captured from the Moroccans. ${ }^{81}$ During the conflict, the Polisario received advisors for the training of its units mostly from Cuba, and to a lesser extent from North

73 Zunes and Mundy, Western Sahara: War, Nationalism and Conflict Irresolution, 17.

74 Besides various subsidies and aid, Saudi Arabia magnanimously cancelled all the Moroccan debt in 1991, as Morocco participated with a 2,000-strong military unit in the First Gulf War, that raged between the U.S. and its allies, and Iraq.

75 Libya formerly supported the guerrillas of the Polisario, providing them with arms, training and logistical support. However, in 1984, Kadhafi signed the Oujda Treaty with Hassan II, in which he recognized Morocco's claim to Western Sahara and agreed to uphold the freshly instituted embargo against the Sahrawis. Later, the relationship between Libya and Morocco worsened and Libya started to support the Polisario again, but more moderately.

76 The Spanish - besides the arms sales - organized a military and police training for the Moroccan armed forces which underwent a swift increase in its numbers.

77 Zunes and Mundy, Western Sahara: War, Nationalism and Conflict Irresolution, 87.

78 Raphael Mergui, "Sahara: La Grande Riposte," Jeune Afrique, November 21, 1979, 2330.

79 Jensen, War and Insurgency in the Western Sahara, 17, 35.

80 Interestingly, the Soviet Union and the Socialist countries (with the exception of Cuba and Yugoslavia) did not recognize the country proclaimed by the Sahrawis and did not provide direct military support for the Polisario. See: Zoubir, "The Western Sahara Conflict," 234; Hodges, "The Western Sahara File," 112.

81 Paul, et al., With the Polisario Front of Sahara, 21. 
Korea and the German Democratic Republic, ${ }^{82}$ who were only active in Tindouf, not in the main area of operations. ${ }^{83}$

While Moroccan superiority was indisputable, the guerrillas still managed to capture the well-fortified garrison of Lebuirat on 24 August $1979 .{ }^{84}$ The city and the barracks were defended by 1,000 soldiers of the $3^{\text {rd }}$ Armored Infantry Regiment of the Royal Moroccan Army. The attackers had already launched two unsuccessful assaults against the city, and while they could not capture it, they managed to weaken the garrison significantly. The fighting morale of the Moroccan troops was already low due to four years of continuous service without leave. The commander of the unit, Lieutenant-Colonel Mohammed Azelmat, requested immediate assistance from his superiors, but they did not take his warning seriously. In addition, heavy sandstorms caused serious problems for the Moroccan air force; the planes could not take off, thus the surrounded garrison did not receive any air support. Moreover, a unit sent to relieve the garrison was ambushed by Polisario units near Zag and forced to retreat.

In the attack of 24 August, the invading Western Saharans eliminated all opposition in less than 40 minutes and occupied the garrison for more than 24 hours. According to reports, the Moroccan losses were serious; there were 562 dead, several tanks and armored vehicles were destroyed and the attackers captured 111 soldiers, along with 37 T-54 tanks and several hundred small arms.

Inspired by their success, the units of the insurgents launched further attacks. For example, on 5 October, they laid down fire on the South Moroccan city of Zag as a diversion, so that on 6 October they were able to capture the second largest Western Saharan city, Smara. ${ }^{85}$ The city was well fortified by the Moroccans, and Mirage planes were also stationed at its airport. During the fight, the Royal Moroccan Army deployed about 5,400 well-equipped soldiers and Mirage F-1 fighter planes against the insurgents. ${ }^{86}$ In spite of this, the attackers triumphed. In the battle, the Moroccans lost 121 soldiers, including the commander of the Moroccan troops, Colonel Driss Harti. Moreover, the 700 Sahrawis living in the city were evacuated to Algeria by the Polisario. ${ }^{87}$

The next battle ensued at the city of Mahbas, 60 kilometers from the Algerian border. The civilian populace had already fled from the city in 1975, thus the Moroccan soldiers were using it as a forward outpost in order to prevent the infiltration of Polisario troops. This outpost was defended by 780 soldiers against a 1,200-strong attacking force. In the 24-hour-long battle, the numerically superior attackers won, and also managed to defeat extra troops arriving from Zag to

82 Gareth M. Winrow, The Foreign Policy of the GDR in Africa (Cambridge: Cambridge University Press, 1990), 143.

83 Jensen, War and Insurgency in the Western Sahara, 50.

84 Besenyő, A nyugat-szaharai válság egy magyar békefenntartó szemével, 146-147.

85 Thompson and Adloff, The Western Saharans, 253.

86 Dean, The Air Force Role in Low-intensity Conflict, 44.

87 Hodges, "The Western Sahara File," 104. 
relieve the outpost. According to the report of the Moroccan military leadership, more than 20 percent of the garrison's manpower were killed and even more were wounded. ${ }^{88}$ The targets of the next attacks were the city of Tata and the oasis M'hamid, where Mohammed V had first announced his country's claims on the Western Saharan territories.

William $\mathrm{H}$. Lewis, a known military analyst, later wrote about the failure of the Moroccan military saying that: "The Moroccans had ignored the famous dictum of Frederick the Great: 'He who attempts to defend too much defends nothing'. ${ }^{\prime \prime} 89 \mathrm{He}$ argued that the Moroccan units were dispersed over a too large an area, their firepower was dispersed and their logistical lines were overstretched, which allowed them to be weakened by the raids of the insurgents. Thus, they were unable to fight effectively against the Sahrawis. The Moroccan soldiers had great difficulty in adapting to the Western Saharan conditions and climate, they were unmotivated and underpaid, and their officers were unable to develop efficient COIN tactics and apply them against the insurgents. Moreover, they lacked effective military and leadership skills.

The Moroccan military units were also hampered by some serious communication issues. After two unsuccessful attempts on his life, Hassan II did not trust the leading officers of the military. So, only the Royal Court could authorize any troop movements or other military activities. Lacking authorization, none of the commanders of Moroccan units dared to act or coordinate their activities as this might have been considered by the supervising Royal Gendarmerie as a conspiracy. Consequently, by the time permission arrived, the guerrillas had already vanished. ${ }^{90}$

\section{The Change in Moroccan Strategy}

The increasing attacks shocked the Moroccan military and the political leadership, who realized that the tactics they had been using so far had not been able to defeat the Polisario. Furthermore, they were increasingly afraid that Morocco would have to retreat from Western Sahara which could have resulted in unforeseeable consequences for the Royal family and the political-military leadership of the country. One man did not share these feelings of desperation, General Amed Dlimi, the main confidant of the king, who asked for and received absolute power for the control of the Saharan operations.

He first dismantled the military bases in the desert that he deemed undefendable, then he concentrated all the Moroccan troops in the districts of Boukra, El-Aaiun and Smara. Following this reorganization and concentrated training of the troops, a number of operations were launched against the guerillas on 5 November 1979. 7,000 soldiers and several Mirage and F-5 fighter aircraft were deployed in the operation. Learning from the failures of previous op-

\footnotetext{
88 Hodges, Western Sahara: Roots of a Desert War, 287.

89 Zunes and Mundy, Western Sahara: War, Nationalism and Conflict Irresolution, 15-16.

90 Jensen, War and Insurgency in the Western Sahara, 47.
} 
erations, the General employed Sahrawis who knew the desert well during the clashes, ${ }^{91}$ and removed the civilian population living in the area of operation, so that they would not be able to provide support for the militants of the Polisario. ${ }^{92}$ Building upon the experiences of their failures, the Moroccans replaced the slow-moving military convoys with well-armed, fast-moving squads with jeeps. ${ }^{93}$ The Green Berets of the U.S. military provided assistance in the training of Moroccan troops and, in many cases, they accompanied them in Moroccan uniforms to the area of operations. ${ }^{94}$

During one operation, a convoy of 1,500 armored vehicles and 6,000 soldiers moved from the city of Tan-Tan to Dakhla, eliminating several armed groups on the way. ${ }^{95}$ The operation lasted more than three weeks, but the Moroccans did not encounter serious resistance as the guerrillas evaded open conflict. Therefore, the operation could only be regarded as a display of power, because the Moroccans were unable to achieve any lasting results. Two journalists of the Jeune Afrique, Raphael Mergui and Pascal Maitre, were allowed to join the Moroccan troops and provided first-hand reports to their readers about the operation. ${ }^{96}$ In the next operation (Operation Zelleka) the Moroccans attacked insurgent camps in the Quarkaziz mountains and then relieved the besieged city of Zag. The Moroccans then stabilized the positions of their troops in the areas between the Zini mountains and the city of Smara, moving close to the Algerian border and establishing strong defensive positions. However, no consequent military actions were performed near the Algerian border.

The Polisario did not give up the fight though and, in early 1980, its forces attacked Tarfaya, the city of Boujdaor, and then the Moroccan troops stationed in the Ouarkziz Valley and the Tigzert Highlands. ${ }^{97}$ The city of Akka was attacked again in the following September, and successful raids were also organized against European fishing vessels and those of other nationalities along the West-

91 While most of the Sahrawis supported the Polisario, several thousand of them served in the Moroccan Royal Army, where they were organized into distinct units. The most famous of their units were the $8^{\text {th }}$ Infantry Regiment and the Makhzen (partisan hunter) units. Most of them were recruited from the South Moroccan region, where the soldierly Sahrawi tribes with military experience and traditions lived. The tribe that provided the most troops for the Moroccans was the Ait Oussa tribe belonging to the Tekna tribal confederation, who maintained a traditionally hostile relationship with the Reguibat tribe. Some Sahrawis, who formerly served in the Polisario units but were captured, were recruited in the freshly established units and undertook service in the Moroccan military in exchange for the freedom of their families and themselves.

92 Jensen, War and Insurgency in the Western Sahara, 44.

93 Cordesman, A Tragedy of Arms, 63.

94 Kamil, Fueling the Fire, 69-70.

95 Anthony G. Pazzanita and Tony Hodges, Historical Dictionary of Western Sahara, $2^{\text {nd }}$ edition (Metuchen, NJ: Scarecrow Press, 1994), 312-313.

96 Mergui, Sahara: La Grande Riposte, 23-30.

97 Lawless and Monahan, War and Refugees, 105. 
ern Saharan coast. ${ }^{98}$ One of the greatest victories of the insurgents was achieved on 31 October 1981, near Guelta Zemmour, where the Moroccans-besides a significant loss of manpower-also lost five of their aircraft. ${ }^{99}$

In spite of this, the Polisario became more and more at a disadvantage compared to the Moroccan army. The main reasons behind their early victories, besides the superior motivation and the effective guerrilla tactics of the Sahrawis, were the armaments provided by the Algerian government, the refugees camps which they used as bases, the weakness of the Mauritanian army and the failures of the Moroccan leadership. Following the withdrawal of Mauritania from the conflict and the removal of the majority of the incompetent leaders in the Moroccan army, the guerrillas lost most of their advantage. General Dlimi contributed to this when in May 1980, recognizing the ineffectiveness of the Moroccan strategy so far, he developed the strategy of walls or "Berms" on the Algerian and Mauritanian border, in the framework of which the strategically important Boucra-El-Aaiun-Smara area (the "useful triangle") was literally barred by the Moroccans.

The aim of this newly established fortification system was not to sever the supply lines of the insurgents, but to keep them away from the Saharan territories valuable to the Moroccans, and to legitimize and finalize the occupation of the territory. Morocco first constructed barbed wire barriers and trench systems, then started to build new walls made of sand and stones. ${ }^{100}$ The Sahrawis launched attacks against the wall at the beginning of their construction, destroying lots of machinery, but they could not hinder the construction work completely. ${ }^{101}$ The construction of the first wall was started in 1981 and finished in 1982. It stretched from the city of Smara to the southern part of Boujdour, where it reached the ocean. ${ }^{102}$ Since then more walls have been built, thus the system of walls today reaches a length of 2,700 kilometers, incorporating 300 fortified positions and observation posts. ${ }^{103}$ In a 5-kilometre-wide stretch in front of the wall, the Moroccans deployed a minefield, which is the largest continuous minefield in the world and still claims lives today.

Between 100,000 and 170,000 soldiers serve in this system of fortifications. ${ }^{104}$ The Moroccans used this wall system, the biggest in the world, to enclose about 80 percent of Western Sahara, which they considered to be the "useful" part, while the undefendable wasteland was left to the Polisario. The Mo-

98 Zunes and Mundy, Western Sahara: War, Nationalism and Conflict Irresolution, 1617.; G. Jensen, War and Insurgency in the Western Sahara, 22.

99 Two pieces of F-1, an F-5, a C-130 and a troop carrier. See: Jacob Mundy, "The Morocco-Polisario War for Western Sahara," in Conflict and Insurgency in the Contemporary Middle East, ed. Barry Rubin (London: Routledge, 2009), 220.

100 Macqueen, United Nations Peacekeeping in Africa Since 1960, 239.

101 Zunes and Mundy, Western Sahara: War, Nationalism and Conflict Irresolution, 20.

102 Dean, The Air Force Role in Low-intensity Conflict, 46.

${ }^{103}$ Cordesman, A Tragedy of Arms, 62.

104 Jensen, War and Insurgency in the Western Sahara, 49. 
roccans withdrew all their forces from that area. ${ }^{105}$ The defense system was completed in 1987 and successfully prevented the Polisario from operating from bases in the occupied territories and significantly limited the military activities of the guerrillas, even though it could not stop them completely. After all, the Sahrawis were capable, in many cases, of launching coordinated attacks against parts of the Berm by removing the mines deployed in front of the wall by night, cutting the barbed wire and assaulting isolated guard posts. However, they had to withdraw swiftly after these successfully executed attacks, as the rapid deployment forces would be already en route to their position. ${ }^{106}$ The insurgents often executed attacks by throwing the removed Moroccan mines over the walls among the soldiers stationed there. ${ }^{107}$ During the construction of the Berm, the Polisario continuously attacked the Moroccans: for instance, the settlement of Lemseid was under fire by Soviet-made rocket launchers on the summer of 1983. Then five motorized infantry battalions and two armored battalions executed an attack against Smara in September. ${ }^{108} \mathrm{~A}$ month later, the guerrillas shot down a Moroccan F-1 Mirage fighter aircraft with an SA-8 (GECKO) missile. In 1984, they launched the "Great Maghreb offensive" in the southern territories against Dakhla and Argoub, then the city of Zag was attacked again, and another Mirage fighter was shot down in early 1985. In 1987, 16 assaults were launched against the Moroccan units, in which they suffered severe casualties. The units of the Polisario launched a large-scale attack against the Moroccan units stationed in the area of Oum Dreyga in September 1988. ${ }^{109}$ Other clashes were also reported near the settlements of Mahbas, Awsard, Guelta Zemmour, Farsiyah, Hausa and Jdyriya.

While it seemed that the Polisario had the initiative, in reality the Moroccans had forced the organization into the very tactics-offensive operations with larger forces - that the Polisario had knowingly avoided so far. After all, in these really costly attacks, the Sahrawis suffered considerable casualties in both manpower and technical equipment against the new defensive tactics of the Moroccans. The more effective Moroccan units, that had much improved leadership and reacted faster than before, managed to force the Sahrawis out of Western Saharan territory, thus the Sahrawis were unable to execute further military op-

105 Hodges, "The Western Sahara File," 105.

106 One of the attacks executed by the Sahrawis at the end of February 1987 against two Moroccan outposts near El Farsi was so successful that the Moroccan king, Hassan II himself had to call to account the general responsible for the district. The report about the incident criticized Moroccan military intelligence and also pointed out that the units stationed on the walls were short of anti-armor weapons; the equipment of the rapid deployment forces also left much to be desired. These experiences were later used by the Moroccans to improve the efficiency of their units. See: Jensen, War and Insurgency in the Western Sahara, 51.

107 Quote from the author's interview in 2004 with Salek ben Mohamed, who served in Camp Mehaires.

108 Jensen, War and Insurgency in the Western Sahara, 50-51.

109 Zoubir, "The Western Sahara Conflict," 228-229. 
erations. From now on, while the Sahrawi insurgency could not be completely eliminated, the Moroccans controlled the conflict, which has slowly died down. The disadvantage of the Sahrawis was further increased by a Moroccan leadership that strived to win over the loyalty of the Sahrawi populace in the occupied territory by providing them with certain possibilities and benefits, with tangible results. ${ }^{110}$

\section{The Way to Agreement, the End of the War}

While the Sahrawis achieved some diplomatic success, they were put more and more at a disadvantage as, due to the considerable fall in global oil prices, the Algerian government significantly reduced their financial and military support during 1986. This contributed to the fact that the Sahrawis were only able to execute small-scale attacks against the Moroccan units. By then, the Sahrawis also knew that they would not be able to win by military means. The Moroccans also recognized the hopelessness of the continuation of the conflict since, while they "secluded" from Western Sahara the natives who fought them, they could only have won eventually by attacking the Polisario in Algeria and risking an unwinnable war with Algeria. Consequently, while they were still fighting each other, a slow rapprochement between the two sides began.

On 22 November 1988, the United Nations called on the two sides to begin talks as soon as possible. Subsequently, the Moroccan ruler agreed to meet the leaders of the Polisario in Marrakesh between 4 and 5 January 1989. The meeting was not successful and the talks did not continue due to differences between the opposing parties. The Polisario then threatened the representatives of the United Nations with continuation of the war with Morocco and, calling off the ceasefire that was announced less than a month before, launched multiple attacks against the Berm, where the defending Moroccan soldiers suffered heavy casualties. $^{111}$

In the summer of 1991, the relationship between Morocco and the Polisario deteriorated further, as the Sahrawis were not willing to withdraw their forces to Tindouf and, moreover, they established new bases in areas east of the Moroccan fortifications. The units of the Moroccan military launched "Operation Rattle" against the insurgents ${ }^{112}$ in the areas of Bir Lahlou and Tifariti between 4 and 29 August, provoking them into a counterattack, thus the almost two-yearlong ceasefire was interrupted again by open conflict. ${ }^{113}$ While Morocco achieved major successes, it did not pursue the retreating Sahrawis into the Al-

\footnotetext{
110 Jensen, War and Insurgency in the Western Sahara, 10.

111 Zunes and Mundy, Western Sahara: War, Nationalism and Conflict Irresolution, 183.

112 Also known as the "Tifariti Offensive."

113 "1991 Tifariti offensive," accessed June 4, 2017, https://www.revolvy.com/main/ index.php?s=1991\%20Tifariti\%20offensive.
} 
gerian refugee camps and thus could not eliminate all of their military strength, being afraid of a conflict with Algeria. ${ }^{114}$

To avoid a further escalation of the situation, the Secretary-General of the United Nations, Pérez de Cuéllar, initiated talks with Morocco, and announced a ceasefire effective from 6 September, without informing the Polisario. Since the Moroccans had achieved their goal, they retreated behind the Berm and the Polisario did not have the strength to execute a counterattack. At this time, the UN Secretary-General approved the immediate deployment of 100 peacekeepers, their numbers were afterwards increased to 228. Along with the military contingent, civilian officials also arrived from other UN missions. Thus, the SecretaryGeneral, without the consent of either of the opposing forces, had separated the ceasefire from other parts of the UN plan and, at the same time, the roadmap approved by the Security Council became meaningless. In this situation, the Polisario had no other choice but to accept the truce, otherwise it would have been shown to be the one that had undermined the fragile peace. The peacekeepers who arrived in the area on 5 September set up their headquarters in Laayoune and, on 15 September, they established three regional headquarters with ten camps in the Northern, Central and Southern sectors. At the same time, a Liaison Office was also established in Tindouf.

The presence of UN troops effectively contributed to the lessening of the conflict, even though the opposing forces had continuously broken the rules of the ceasefire. ${ }^{115}$ For instance, the Polisario complained that Moroccan fighter aircraft continuously violated the Polisario-controlled airspace, while Morocco accused the Sahrawis of entering the occupied territories at weakly controlled points of the Berm. In spite of these infringements, this was the end of this period of the conflict, and the opposing sides now fought only at the negotiating table. The situation now seems to be completely frozen. The presence of UN troops will be required in the future in order to keep the conflict at this level because a mutually acceptable, permanent solution does not seem to be imminent.

\section{Conclusion}

This article has explained how a local conflict began and how it expanded into a regional level exceptionally quickly and in which the opposing forces used tactics specific to COIN operations. In the first part of the conflict, the guerrilla tactics of the Sahrawi insurgents clearly succeeded against Mauritania. However, these tactics were only partly effective against the politically, economically and militarily stronger Morocco. The Moroccan leadership learned from its own, and the Mauritanian, failures and managed to gain military superiority by the combina-

114 Jensen, War and Insurgency in the Western Sahara, 17.

115 "Report of the Secretary-General on the situation concerning Western Sahara," UN Document S/23299, accessed June 4, 2017, http://repository.un.org/handle/11176/ 56600 . 
tion of different combat techniques and then barring the militants of the Frente Polisario from the Moroccan-occupied territories by the strategy of constructing walls. Besides military steps, the Moroccans also gained both diplomatic and economic advantage. Thus, they could first degrade the conflict to low intensity, then totally marginalize it after the ceasefire. In fact, they have managed to achieve victory over the guerrillas, whose chance for another successful war is minimal.

\section{About the Author}

János Besenyő is a Colonel of the Hungarian Defense Forces (HDF), and commissioned head of the Department of Doctrine Concept Development of the HDF's Training and Doctrine Centre. The author holds a PhD in Military Science. He is an expert on peacekeeping operations in Africa and focuses on the Western Saharan conflict. 